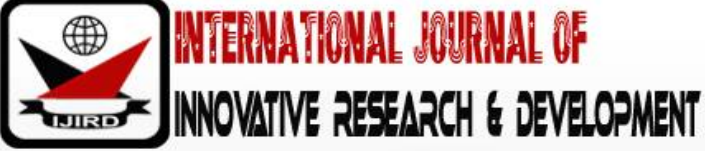

ISSN 2278 - 0211 (Online)

\section{Proximate Composition and Phytochemical Screening of Combretum Hereroense Seed Powder}

\author{
Ndlovu Na \\ Lecturer, Department of Food Science and Nutrition, Midlands State University, Zimbabwe \\ Nkosinomsa Ndebele, \\ Brewing Technician, Department of Brewing, Delta Beverages, Zimbabwe \\ Siwela Nc \\ Intern Lab Technician, Department of Higher Learning, Pearaon Institute, Midrand
}

\begin{abstract}
:
The objective of the study was to investigate the nutritional and phytochemical properties of Combretum hereroense tea so as to determine its safety and quality. Two solvents; water and methanol: ethanol (50:50, v/ v) were used to obtain extracts from the powdered seed. The extracts were subjected to qualitative phytochemical screening using standard procedures. Standard methods were used to measure proximate composition (moisture, crude fibre, crude protein, fat and carbohydrate). The tea was analysed for flavonoids, phenols, alkaloids, saponins, tannins, terpenoids, steroids, glycoside and anthraquinones. The proximate analyses showed that both extracts exhibited a low-fat content, high fibre and the highest value of carbohydrate. Phytochemical screening revealed the presence of six (alkaloids, glycosides, saponins, flavonoids, phenols and tannins) out of nine of the phytochemicals that were screened. The methanol: ethanol extract revealedone more phytochemical property (phytosterols) that was not found in the aqueous extract. Both extracts did not possess terpenoids, quinones and anthraquinones. Chereroense tea has the potential to contribute positively to the health of consumers as a beverage.
\end{abstract}

Keywords: Combretum hereroense, extraction, phytochemicals, proximate, tea

\section{Introduction}

Plants used as food vary from region to region depending on availability and acceptability by people in each region. Some plants are important sources of traditional beverages including herbal indigenous tea plants for example tea brewed from Combretum hereroense seeds (Motlhanka et al, 2008). Tea is consumed for its attractive aroma and taste as well as the unique place it holds in the culture of many societies.In recent years, tea and particularly herbal tea gained increasing consumer attention due to a growing awareness of health benefits derived from their consumption (Aoshima et al, 2007;McKay and Blumberg, 2002). Therefore, tea belongs to a rapidly expanding market of 'wellness beverages' (Byun and Han, 2004).

Combretum hereroense also known as the mouse eared Combretum or Russet bush willow, belongs to the family Combretaceae which consists of 18 genera with the largest genus, Combretum composed of about 370 species (Lawrence, 1951). This tree is most often seen around pans, in rocky areas and sometimes on-stream banks. Russet-Bush willow is a member of the Combretum family and has the characteristic four winged pods with brown seeds found in the centre. It is common in the lowveld and usually seen in closely associated groups. It has an overall coppery appearance often from January to July owing to the presence of large numbers of red brown pods (Drummond, 1981). The seeds of Combretum hereroense are roasted and ground to a fine composite powder which is brewed in water to make a pleasant tea. Tea from seeds of Combretum hereroense is consumed in many rural areas in Zimbabwe while scarce scientific data on the composition of the tea exists.

A decoction of the root bark of $C$ hereroense has been used as a remedy for heart diseases (Mabogo, 2012). Many studies have revealed that plants possess antioxidant compounds which have anti-inflammatory, antimutagenic, antiatherosclerotic, antitumor, anticarcinogenic, antibacterial, and antiviral activities (Ivanisova et al., 2013). There is a growing interest in the use of the natural phytochemicals present in berry crops, teas, herbs, oilseeds, beans, fruits and vegetables because of their health benefits (Kittset al, 2000).

WHO, (2001) reported that 50-80\% of the population of developed and developing countries are mostly relying on herbal plants for disease prevention and promotion of health. Herbal medicines include herbs, herbal materials, herbal preparations, and finished herbal products that contain parts of plants or other plant materials as active ingredients (Fawzi, 2013;Scalbert et al, 2005). Herbal teas can easily be prepared from any part of a plant mainly its roots, seeds, flower, bark and berries. Often the preparation of a herbal infusion may consist exclusively of one or more herbs and is performed by means of decoction, infusion or maceration (Visser, 2015). Plants typically contain mixtures of different 
phytochemicals, also known as secondary metabolites that may act individually, additively, or in synergy to improve health (Srinivasahan and Durairaj 2014).

Phytochemical analysis is very important as a key step to investigate the chemical composition of herbal tea and ensure its quality and safety (Zhao et al, 2013). Thus, the present work was designed to carry out proximate analysis and to screen for phytochemical constituents of Combretum hereroenseseed powder. Knowledge of the phytochemicals contained in the seed powder is key to the safety of the consumers.

\section{Materials and Methods}

\subsection{Study Setting}

Extraction and chemical assays were done in the Food Chemistry lab, in the department of Food Science and Nutrition at the Midlands State University.

\subsection{Source and Processing of Combretum Hereroense}

Combretum hereroense fruits were harvested from 5randomly selected trees in Gwanda District of Matebeleland South Province in Zimbabwe ( $29^{\circ}$ E, 21ㅇ S). The fruits were sorted to remove dirt and leaves after which the pods were manually removed to get the seeds. The seeds were roasted at $65^{\circ} \mathrm{C}$ for an hour and the seeds were crushed using a pestle and mortar to produce a powder which was then roasted at $65^{\circ} \mathrm{C}$ for 30 minutes. The powder was sieved to produce a fine composite powder and stored in glass vials at $4^{\circ} \mathrm{C}$ awaiting extraction and the respective assays.

\subsection{Determination of Proximate Composition of Combretum Hereroense Seed Powder}

\subsubsection{Extraction}

One hundred grams of powdered Combretum Hereroense were extracted by maceration (Chandran et al., 2012) using either distilled water or methanol: ethanol $(50: 50 ; \mathrm{v} / \mathrm{v})$ solvent in a conical flask for 24 hours, filtered and evaporated by a rotary evaporator at $40^{\circ} \mathrm{C}$. The resulting solution was dried in an oven for 24 hours and the extracts kept at $4^{\circ} \mathrm{C}$ until use.

\subsubsection{Determination of Proximate Composition}

Fat from the Combretum hereroense powder was extracted in diethyl ether as described by the Association of Analytical Chemists (AOAC, 2000: method number 920.39). The moisture, ash, crude protein and carbohydrate content of the $C$ hereroense powder were determined as described by the Association of Analytical Chemists (AOAC, 2000: Methods 934.01 and $930.15,942.05$ and 954.01, respectively). Each assay was carried out in duplicate.

\subsubsection{Determination of Phytochemical Composition}

\subsubsection{Determination of Alkaloids}

Mayer's test was used to determine the presence of alkaloids (Vijayalakshmi et al., 2012). 50mg of solvent free extract was stirred in $3 \mathrm{ml}$ of dilute hydrochloric acid then filtered thoroughly using Whatmann's filter paper no. 1. Three drops of Mayer's reagent were added to $1 \mathrm{ml}$ of the filtrate and a white creamy precipitate indicated the presence of alkaloids.

\subsubsection{Determination of Phytosterols}

Phytosterols were determined by the Liberdmann-Burchad's test as according to Vijayalakshmi et al., (2012) with slight modifications. Briefly 50mg of extract was dissolved in $2 \mathrm{ml}$ acetic anhydride then 1 drop of concentrated sulphuric acid added along the side of the test tube. Formation of a blue-green colour indicated the presence of phytosterols.

\subsubsection{Determination of Terpenoids}

Terpenoids were determined as according to the method used byVijayalakshmi et al., (2012). Briefly $2 \mathrm{ml}$ of Chloroform and concentrated sulphuric acid were carefully added to $0.5 \mathrm{ml}$ of extract. A red brown colour at interface indicated presence of terpenoids.

\subsubsection{Determination of Glycosides}

Legal's test was performed according toVijayalakshmi et al., (2012) to determine the presence of glycosides. Briefly $2 \mathrm{ml}$ chloroform and 10\% Ammonia solution were added to $2 \mathrm{ml}$ of the Chereroense seed extract. The formation of a pink colour confirmed the presence of glycosides.

\subsubsection{Determination of Saponins}

A froth test was done to determine the presence of saponins where $2 \mathrm{ml}$ of distilled water were added to $5 \mathrm{~g}$ of the extract and the resulting mixture was agitated vigorously for 7 minutes. Foam production confirmed the presence of saponins ( Liu et al, 2009).

\subsubsection{Determination of Flavonoids}

$3 \mathrm{ml}$ of $2 \%$ sodium hydroxide were added to $3 \mathrm{ml}$ of the extract. The colour changes were recorded and a yellow colour signifies flavonoids presence (Liu et al., 2009). 


\subsubsection{Determination of Phenols}

The presence of phenols was determined by the Lead acetate method as accordingto Vijayalakshmi et al., (2012). Briefly, $5 \mathrm{mg}$ of the seed extract was dissolved in distilled water and $3 \mathrm{ml}$ of $10 \%$ lead acetate solution was added. A bulky white precipitate indicates the presence of phenols.

\subsubsection{Determination of Quinones}

Concentrated sulphuric acid $(1 \mathrm{ml})$ was added to $1 \mathrm{ml}$ of the seed extract. A red colour indicated the presence of quinones (Vijayalakshmi et al., 2012).

\subsubsection{Determination of Anthraquinones}

The presence of anthraquinones was determined by adding 3 drops of $2 \%$ hydrochloric acid to $0.5 \mathrm{ml}$ of the seed extract. A red coloured precipitate indicated the presence of anthraquinones (Vijayalakshmi et al., 2012).

\subsubsection{Determination of Tannins}

The presence of tannins was determined using the ferric chloride test where $5 \mathrm{mg}$ of extract was dissolved in $5 \mathrm{ml}$ of distilled water and 3 drops of neutral $5 \%$ ferric chloride solution added. A blue green colour indicated the presence of tannins (Vijayalakshmi et al., 2012).

\subsection{Statistical Analysis}

Data is expressed as mean \pm SD. Graph Pad Prism Version 5 (Graph-pad Software Inc., San Diego, USA) statistical package was used to analyse data. An unpaired t- test was used to analyse the data. The level of significance was set at $\mathrm{P}<0.05$.

\section{Results and Discussion}

\subsection{Proximate Composition of Combretum Hereroense Seed Powder}

The results of proximate composition of Combretum hereroense seed powder are shown in table 1.Both the aqueous and methanol: ethanol $(50: 50 \mathrm{v} / \mathrm{v})$ extracts were observed to have a low-fat content $(2.53 \%$ and $2.64 \%$ respectively), high crude fibre (34.81\% and 35.02\% respectively) and the highest value for carbohydrate content ( $43.21 \%$ and $43.17 \%$ respectively).The methanol: ethanol extract revealed a significantly higher crude fibre content compared to the aqueous extract. Crude fibre serves to enhance the efficiency of digestion by stimulating peristaltic action and enhancing the movement of food through the alimentary canal. It is also known to prevent colon cancer. Food fibre has been shown to aid absorption of dietary minerals as well as reduce absorption of cholesterol (Aliyu et al., 2009). In tea however, crude fibre improves the sensory appeal of the beverage by providing a filter system to prevent the leaching of plant material from the tea bag into the infusion (Waldron et al, 2003). Previous researchers also indicated positive association between fibre content and keeping quality of the tea.

\begin{tabular}{|c|c|c|c|}
\hline Parameter (\%) & Aqueous & Methanol: Ethanol & P-value \\
\hline Moisture & $10.05 \pm 0.02$ & $10.02 \pm 0.01$ & 0.0955 \\
\hline Crude Fibre & $34.81 \pm 0.01^{\mathrm{b}}$ & $35.02 \pm 0.02^{\mathrm{a}}$ & 0.0478 \\
\hline Crude protein & $4.01 \pm 0.03$ & $3.83 \pm 0.02$ & 0.0896 \\
\hline Fat & $2.53 \pm 0.01$ & $2.64 \pm 0.10$ & 0.3652 \\
\hline Ash & $5.03 \pm 0.14$ & $5.25 \pm 0.01$ & 0.2698 \\
\hline Carbohydrate & $43.21 \pm 0.01$ & $43.17 \pm 0.02$ & 0.2396 \\
\hline
\end{tabular}

Table 1: Proximate Composition of Combretum Hereroense Seed Powder a, b within Row Means with Different Superscripts Differ Significantly at $\mathrm{P}<0.05$ Data Is Expressed as Mean $\pm \mathrm{SD}$

\subsection{Qualitative Phytochemical Analysis of Combretum Hereroense Seed Powder}

The results of the phytochemical content of Combretum hereroense seed powder are shown in table 2.Non- polar solvents yield more lipophilic components, while alcoholic solvents give a larger spectrum of polar material. Therefore, as can be seen in table 2 it was easier to detect steroids in the Methanol: Ethanol extraction unlike the aqueous one since methanol has the ability to dissolve both polar and non-polar materials. Natural products belonging to saponins, phenols, tannins, and flavonoids were all shown to be present in both the aqueous and methanol: ethanol extract. The aqueous extract was used in this study since the $\mathrm{C}$ hereroense seeds are usually used as a hot water decoction to make tea. The estimated amount of phytochemicals detected in the extracts was based on the intensity of colour change observed during screening. Saponins have been reported to possess analgesic properties and central nervous system activities (Mandal et al, 2001), while Podolak et al., (2010) have reported cytotoxic effects of saponins. Table 2 shows the presence of tannins in $\mathrm{C}$ hereroense tea. Tannins have traditionally been considered anti-nutritional, however the effect of their anti-nutritional properties depend largely on their chemical structure and dosage. It has been reported that if ingested in excessive quantities, tannins inhibit the absorption of minerals, such as iron which may, if prolonged, lead to anaemia. Lalitha, (2012) added that tannins are known to inhibit pathogenic fungi which threaten human health, therefore the consumption of teas containing tannins can contribute positively to the health of consumers. Tannins are used as antiseptic and this activity is due to presence of the phenolic group. Common examples of hydrolysable tannins include theaflavins (from tea), 
daidezein and genistein. In Ayurveda, formulations based on tannin-rich plants have been used for the treatment of diseases like leucorrhoea, rhinorrhoea and diarrhoea(Doughari et al ,2009).

Sterol is soluble in ethanol to a small extent because of some hydroxyl groups present in its structure. The study showed the presence of sterols in the Methanol: Ethanol extract (table 2). However, sterols are not soluble in water because of their large size; solvation in water is not possible.Terpenoids were found present in both aqueous and Methanol: Ethanol extracts. Terpenoids have been shown to decrease blood sugar level in animal studies (Mandal et al, 2009). Table 2 indicates the presence of alkaloids in C. hereroense seed powder.Research shows that alkaloids exhibit marked physiological effects such as antibacterial (Mabhiza et al., 2016) and analgesic effects. Flavonoids are phenolics compounds and act as primary antioxidants (Abdel-moneim et al, 2012). Flavonoids were found to be present in both extracts (Table 2).Flavonoids play an important role in bio- activities of tea (Anesini et al, 2008). The chemical composition of tea varies and largely depends on climatic conditions, horticultural practices, soil, growth altitude (Pelillo et al, 2002).The phenolic hydroxyl group in flavonoids is a strong antioxidant capable of effectively scavenging reactive oxygen species (Prior et al, 1999).

\begin{tabular}{|c|c|c|}
\hline Parameter & Aqueous & Methanol: Ethanol \\
\hline Alkaloids & + & + \\
\hline Steroids & - & - \\
\hline Terpenoids & - & + \\
\hline Glycosides & + & + \\
\hline Saponins & + & + \\
\hline Flavonoids & + & + \\
\hline Phenols & + & - \\
\hline Quinones & - & - \\
\hline Anthraquinones & - & + \\
\hline Tannins & + & + \\
\hline
\end{tabular}

Table 2: Phytochemical Properties of Combretum Hereroense Seed Powder +. Present; -: Negative

\section{Conclusion}

We conclude that $\mathrm{C}$ hereroenseseed powder has the potential to benefit the health of consumers if consumed as a tea. However, $\mathrm{C}$ hereroense tea must not be consumed excessively considering the fact that it has tannins which mayinterfere with mineral absorption in the body.

\section{Acknowledgements}

The authors would like to acknowledge the technical assistance provided by the lab technicians in the department of Food Science and Nutrition, Midlands State University.

\section{Conflict of Interest}

The authors declare that they have no conflict of interest.

\section{References}

i. Abdel Moneim, A.E. and K.M. El-Deib, 2012. The possible protective effects of Physalis peruviana on carbon tetrachloride-induced nephrotoxicity in male albino rats. Life Sci. J., 9: 1038-1052.

ii. Anesini, Claudia \& E Ferraro, Graciela \& Filip, Rosana. (2008). Total Polyphenol Content and Antioxidant Capacity of Commercially Available Tea (Camellia sinensis) in Argentina. Journal of agricultural and food chemistry. 56. 9225-9.

iii. AOAC. (2001) Official Methods of analysis, 17th Ed. AOAC International. Gaithersburg, Maryland, USA.

iv. Aliyu, A. B., Musa, A. M., Sallau, M. S. and Oyewale, A, O. (2009). Proximate composition, mineral elements and antinutritional factors of anisopus mannii N.E.Br.(Asclepiadaceae). Trends Applied Science Research 4: 68-72.

v. Aoshima, H., Hirata and Ayabe, S. (2007). Antioxidative and anti-hydrogen peroxide activities of various herbal teas. Food Chemistry103:617-622.

vi. Byun, Jae-Oke \& Han, Jae-Sook. (2004). A Study on Perception and Actual Status of Utilization for Green Tea.Journal of the Korean Society of Food Culture. 19.

vii. Chandran, R., T, Parimelazhagan, Shanmugam, S., Thankarajan, S., and Karuppusamy, A. (2012). Antioxidantand anti-inflammatory potential of Monochoria vaginalis: A wild edible plant. Journal of Food Biochemistry, 36: 421431.

viii. Doughari, J. H., Human, I. S., Bennade, S. and Ndakidemi, P.A. (2009). Phytochemicals as chemotherapeutic agents and antioxidants. Possible solution to the control of antibiotic resistant verocytotox in producing bacteria. Journal of Medicinal Plants Research 3(11): 839-848.

ix. Drummond, R. B. (1981). Common Trees of the Central Watershed Woodlands of Zimbabwe. Natural Resources Board, Harare. 160-161.

x. Fawzi Mahomoodally, M. (2013). Traditional Medicines in Africa: An appraisal of Ten Potent African Medicinal plants. Evidence based Complementary and Alternative Medicine. 
xi. Hertog, M.G.L., Feskens, E.J.M, Hollman, P.C.H., (1993). Dietary antioxidant flavonoids and risk of coronary disease: The Zutphen Elderly Study. Lancet; 342:1007-11.

xii. Ivanisova, Eva \& Tokar, Marián \& Mocko, Karolina \& Bojnanska, Tatiana \& Mareček, Jan \& Mendelová, Andrea. (2013). Antioxidant activity of selected plant products. J. Microbiology, Biotechnology and Food Sciences. 2. 16921703.

xiii. Kitts, D.D., Yuan, Y.V., Wijewickreme, A.N., Hu, C(2000). Antioxidant properties of a North American ginseng extract.Mol Cell Biochem, 203:1-10.

xiv. Lalitha, P. T. and Jayanthi, P. (2012). Preliminary studies on phytochemicals and antimicrobial activity of solvent extracts of Eichhovnia crassipes (Mat) Solns. Asian Journal of Plant Science and Research 2 (2): 115-122.

xv. Lawrence, G. H. M., (1951). The taxonomy of Vascular Plants, MacMillan, New York.

xvi. Liu, N.Q., Van, K.F., Verpoorte, R., (2009). Artemisia afra: A potential flagship for African Medicinal plantsSouth African Journal of Botany 75(2): 185- 195.

xvii. Mabhiza, D., Chitemerere, T. and Mukanganyama, S. (2016). Antibacterial Properties of Alkaloids Extracts from Callistemon citrinus and Vemonia adoensis against Staphylococcus aureus and Pseudomonas aeruginosa. International journal of Medicinal Chemistry.

xviii. Mabogo, (2012). Plants Used by the Vhavenda. University of Pretoria, Chapter 4.

xix. Mandal, S. C., Dhara, A, K. and Maiti, B. C. (2001). Studies of psychopharmacological activity of Andrographis particulate extract. Phytother Res 15: 253-256.

xx. McKay, D. L. and Blumberg, J. B. (2002). The role of tea in human health: an update. Journal of the American College of Nutrition 21, 1-13.

xxi. Motlhanka, D.M.T., Motlhanka, P., Selebatso, T., (2008). Edible Indigenous Wild Fruit Plants of Eastern Botswana. International Journal of Poultry Science. 7(5): 457- 460.

xxii. Pelillo, M., Biguzzi, B., Bendini, A., Gallina Toschi, T., Vanzini, M. and Lercker, G. (2002). Preliminary Investigation into development of HPLC with UV and MS- electroscopy detection for the analysis of tea catechins. Food Chemistry 78: 369-374.

xxiii. Podolak, I., Galanty, A. and Sobowleska, D. (2010). Saponins as cytotoxic agents: a review. Phytochemistry Reviews 9:425-474.

xxiv. Prior, R. L. and Cao G. (1999). Antioxidant Phytochemicals in fruits and vegetables: Diet and Health Implications.Hort Science 35 (4): 588-592.

xxv. Scarlbet, A., Manach, C., Morand, C. and Remesy, C. (2005). Dietary polyphenols and the prevention of diseases. Critical Reviews in Food Science and Nutrition, 48: 287-306.

xxvi. Srinivasahan, V., and Durairaj, B. (2014). Antioxidant and free radical scavenging effect of Morinda citrifona fruit extract. International Journal of Pharma Pharmaceutical Science, 6(4): 55-59.

xxvii. Vijayalakshmi, R., and Ravindhran, R. (2012). Preliminary comparative phytochemical screening of root extract of Diospyrus ferrea(Wild.) Bakh and Aerva Lanata (l.) Juss. Ex Schultes. Asian Journal of Plant Science and Research,2 (5): 581-587.

xxviii. Visser, M. (2015). Using Herbs: Herbal teas, Infusions and Decoctions. Herbal Education 21.

xxix. Waldron, K. W., Parker, M. L. and Smith, A. C. (2003). Plant Cell Wall and Food Quality: A review. Journal of Food Science and Technology 2: 109-110.

xxx. WHO (2008), FactSheet No. 134, http/ / www.who.int/ mediacentre/ factsheets134/ en/ .

xxxi. Zhao, J., Deng, J.W., Chen, Y.W., Li, S.P., (2013). Advanced phytochemical analysis of herbal tea in China. National Library of Medicine Bethesda. 